\title{
Emancipation and Rehabiliation in Manju Kapur's Home: A Study of Family Values
}

\author{
Purneet Kaur \\ $\mathrm{PhD}$. Research Scholar (English) \\ Desh Bhagat University, Mandi Gobindgarh, Punjab
}

\begin{abstract}
The paper focuses upon various important themes of female issues concerning emergence of independent identity of Nisha, a young daughter in the joint family. Her pretense as a self standing woman turns down all the sophisticated family values inevitable for a daughter. Manju kapur, as an accomplished writer of Indian family system, evidences her genuine text in depicting the motif of woman's emancipation and rehabiliation in the patriarchal based society.
\end{abstract}

Manju Kapur emerges as a new prodigy in Indian writing in English born on 25th October in 1948 in Amritsar. She spent her childhood in Washington Dalhousie, Canada and completes her M.A. English from Dalhousie University in Halifax, Nova Scotia, Canada. She worked as a professor of English at Miranda House in Delhi after being awarded M.Phil. degree from Delhi University. She has five novels acclaiming popular success and critical appreciation at the wide level. She emerges as a significant writer in the progression of Indian fiction.

\section{INTRODUCTION}

The fictional women characters of Manju Kapur are supposed to unveil the hidden secrets of penetrating beliefs, customs, rituals and superstitions. They are the rebel of inhibition, societal oppressive expectations, joint family regulations and patriarchal limitations in the society. They are not the muted creatures but are bold enough to raise their voices for their selfhood and oppose the injustice and wrought. Their identity is continuously in dichotomy between their inner aspirations and social mechanisms of surveillance. They reflect futile quests, disappointed dreams, yearning for a home, ruining of identity, struggle for selfhood which leaves behind nothing but anxiety, humiliation and discomfort.

The present paper deals with Manju Kapur's third novel "Home" (2006). The fiction is clear for its focus upon the better off of women's position in a household as well as in a society. Kapur has evoked several societal evils which may include caste based prejudice, classism, superstitious beliefs, prohibited female education, eradication of child marriage etc. The institution of marriage is an intimate oppressor to marginalize women within the society. A girl is never needed to discuss about her marital descendants. Love marriages are preferred as a social sin and worthy of shame while arranged marriages are viewed with the eyes of respect and hope for dowry negotiations. To break the male dominance shackles, a woman requires to question the popular prejudices and to reinvent their identity. However, it is not education only that is needed. It is that women who should have liberty of experience that they should differ from men without fear and express those differences openly....be....encouraged to think, invent, imagine and create as freely as men do" (Woolf 32-33).

The novel "Home" moves forward through the depressing tale of strangely captivated Manju Kapur's woman, Nisha between her innermost desires and family oriented responsibilities and restrictions. The novel is a brisk account of three generations. It is a joint family saga having Lala Banwari lal as its patriarch. It is an extraordinary story of a middle class joint family. Each individual's voice may chatter, complaint, question but all fall silent to the common interests of household as a whole. One genuine problem of any one person is treated with rejection. The depiction of authentic question of one female by another female is the ultimate outcome of the novel. The love marriage of the elder son of Banwari Lal comes up with lots of abused remarks and regarded as a sin. While the arranged marriage of the younger son is cheerfully welcomed and socially applauded as it enables to have dowry benefits. The superstitious beliefs move hand in hand with the story of the novel. Karva Chauth 
for the upcoming husband and keeping a fast are all accepted harmful practices which are weakening the societal stems. The complexities of the novel are numberless as each careful reading explores new dimensions of significance and meaning.

Manju Kapur had started writing this novel in 1994. It could be her first novel if she did not stick to the novel "Difficult Daughter". She acclaims that Home is not about her personal analysis but her intellectual thinking based upon her academic experience. She divulges it in one of her interview, "I can analyze only because I am a teacher." She takes writing as a muscle which needs to be activated all the time. She feels her life completed in teaching, home and writing.

Kapur's new emblematic novel is an intricate story of joint family life. Lala Banwari Lal -the patriarch of the family believes in the old ways. Anupama Chowdhury elaborates:

"Home reveals a disturbing home truth that joint families can both destroy

and preserve our maturity, individuality and mental progress." (Chowdhury, 33).

With the advent of technology, the family in "Home" witnesses a series of new beginnings; to have newly viewed generation, education and above all to find peace.

Men, in the family are carried forward to work outside the home while their wives are implied to play their part within. The tale focuses upon three generations of women - Sona (daughter-in-law of Banwari Lal), Rupa (Sona's sister) and Nisha (Sona's daughter). There are many implications and regulations within the writing which are only needed to be accepted by females. Mostly, it is a female who is imparting compulsions upon another female. Sona, the elder daughter-in-law of Banwari Lal, is forced to pour her motherly emotion into her dead sister-in-law's son against her wishes. She is constrained to submit to fate, "Beti, now you are his mother. God has rewarded your devotion. Sometimes our wishes are fulfilled in strange ways". (p.27).The discriminated feelings of family to her for being childless are comforted only after ten years late birth of her first child, Nisha. Sona, as the victim of subordination and marginalization, now, transforms into the representative of it. The pain she suffers is passed on into another female character of Kapur, Nisha.

The major portion of the novel is devoted to Nisha, granddaughter of Banwari Lal. Through the character of Nisha, Kapur carries forward the picture of our society which portrays the image of a woman as a subjugated being, as a taken-for-granted aspect. However, Nisha's reaction to these antithetical forces presents another surface of the novel. After overcoming her core hardships of life, Nisha does pass through a phase of disappointment but then emerges as an independent financial woman. Nisha's motion of emancipation from border to the mainland cannot be under estimated in the given restricted patriarchal structure of marginality in woman's life.

The birth of Nisha brings luck to the family as her aunt exclaims, "Nisha has opened the luck of his family. I tell you, two children in two years after a decade of draught". Nisha, being luckiest for others, cannot bring it for herself. She is physically exploited in her childhood by her growing cousin, Vicky. Her cries and rebel against those dirty fluctuations are not heard or understood. Her pain comes out in the form of nightmares and sleepless nights. The homily love and care is fetched from her in the childhood as she is distanced to her aunt, Rupa. Her return to her home after so many years is no way approached with great apprehension and gratitude. Her mother, Sona subordinates her into household works. Eventually Nisha, being an intellectual thinker at her aunt's home, loses her academic interest in her college life.

From the traditional Indian society, woman under the patriarchal discrimination is targeted to live and survive social ostracism. They are dealing with unending struggle to enact an equal position to men in the society. Manju Kapur's heroine, Nisha is forced towards domesticity and so-called family rituals under patriarchal notions. She is caught in dichotomy between her personal wants and institutional liabilities. However, Nisha defies the oppressive mechanism of a closed society and asserts her individuality. She nurtures her desire to lead life of her own. She is not a silent rebel but utters her inner urges loudly. She challenges the male exercise of having control over woman's body.

The unmarried women of twentieth century are still considered as a burden on her parents until she is married. She is seen as a spinster or a piece of shame if she marries late. Any love-affair before marriage is a sinful act on the part of girl. Unwed mothers, single or unfaithful women are assigned outcasts. Nisha's relationship with Suresh is looked as a big downfall in the reputation of the family. 
Nisha fights against the bounded norms of the family and to live her life on her own terms. She rejects to marry anyone of her family's choice. But what does she really get? Despite of her hard labour for self-fulfillment, she becomes a loser in her efforts. She is alienated and discriminated in her own family. Her younger brother is married before her which diseases her mentally and physically.

In the novels of Manju Kapur, women are allowed to work outside the home. Even if they are dealing with financial matters or doing any job outside, she is denied of any right on household matters. A wage- earning woman's first duty is to handle the charge of the kitchen before her job. Nisha builds herself as a successful designer but her marriage with Arvind pushes her away from her business. She is enslaved within her family responsibilities; dutiful daughter -in -law and wife, motherhood etc. The end product of Nisha's plight cannot be seen in attainment of victory or defeat but she satisfies her inner urge in her own home, "All mine, she thought all mine". (p 336). Nisha's emancipation for her individuality and independent identity become nothing of use as she is found in rehabilitation as she finds her peace of mind in getting her home, her own.

\section{REFERENCES}

Kapur, Manju. Home. New Delhi: Random House India. 2006. Print.

Jaidev. "Problematizing Feminism." Gender and Literature. Ed. Iqbal Kaur. New Delhi: B.R. Publishing Corporation, 1992. Print.

Ali, Farzana. S. Novels of Manju Kapur: A Critical Study. India: DATTSONS, 2015. Print.

Rajput, Kalpna. Remapping The Female Map: Jhumpa Lahiri and Manju Kapur. Yking Books Jaipur India. 2012. Print.

Sharma, Dr. Ram. Rise of New Woman Novels of Manju Kapur. Manglam Publications Delhi -110053 (INDIA). 2013. Print. 